\title{
Synthesis of Orthogonally Protected 1,2-diaminopropanoic Acids by Ring-Opening of 3-Unsubstituted N-Activated Aziridine 2-Carboxylates with Para-Methoxybenzylamine: a Study of the Regioselectivity of the Reaction
}

Fintan Kelleher

Technological University Dublin, fintan.kelleher@tudublin.ie

Keith O'Brien

Technological University Dublin, x00016514@itnet.ie

Follow this and additional works at: https://arrow.tudublin.ie/ittsciart

Part of the Organic Chemistry Commons

\section{Recommended Citation}

Kelleher, F. and O'Brien, K. Synthesis of orthogonally protected 1,2-diaminopropanoic acids by ringopening of 3-unsubstituted $\mathrm{N}$-activated aziridine 2-carboxylates with para-methoxybenzylamine: a study of the regioselectivity of the reaction. Tetrahedron Letters, October 2013.

This Article is brought to you for free and open access by the School of Science and Computing at ARROW@TU Dublin. It has been accepted for inclusion in Articles by an authorized administrator of ARROW@TU Dublin. For more information, please contact arrow.admin@tudublin.ie, aisling.coyne@tudublin.ie, gerard.connolly@tudublin.ie. Funder: Irish Government

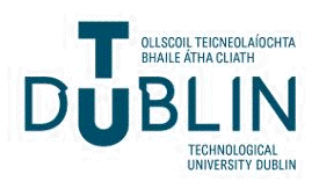


Synthesis of orthogonally protected 1,2-diaminopropanoic acids by ring-opening of 3-unsubstituted N-activated aziridine 2-carboxylates with paramethoxybenzylamine: A study of the regioselectivity of the reaction

Keith O’Brien, Fintan Kelleher*

Molecular Design and Synthesis Group, Centre of Applied Science for Health, Institute of Technology Tallaght, Dublin 24, Ireland.

Corresponding Author: Dr. Fintan Kelleher

Address: $\quad$ Department of Science,

Institute of Technology Tallaght,

Tallaght,

Dublin 24,

Ireland.

Phone Number: (+353 1) 4042869

Fax Number: $\quad$ (+353 1) 4042700

e-mail address: $\quad$ fintan.kelleher@ittdublin.ie

Graphical abstract :

Synthesis of orthogonally protected 1,2-diaminopropanoic acids by ring-opening of 3unsubstituted $\mathrm{N}$-activated aziridine 2-carboxylates with para-methoxybenzylamine: A study of the regioselectivity of the reaction

Keith O’Brien, Fintan Kelleher*<smiles>[R]OC(=O)[C@@H]1BN1[GeH3]</smiles><smiles>[NH3+]</smiles><smiles>COc1ccc(CN)cc1</smiles>

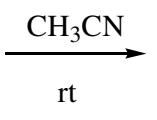

PMB<smiles>[R]OC(CNC)NC(NC)C(=O)O</smiles> 
Synthesis of orthogonally protected 1,2-diaminopropanoic acids by ring-opening of 3-unsubstituted $\mathrm{N}$-activated aziridine 2-carboxylates with paramethoxybenzylamine: A study of the regioselectivity of the reaction

Keith O’Brien, Fintan Kelleher*

Molecular Design and Synthesis Group, Centre of Applied Science for Health, Institute of Technology Tallaght, Dublin 24, Ireland.

\begin{abstract}
:
Orthogonally protected 1,2-diaminopropanoic acids (DAPs) have been synthesised in good yields by the ring-opening of 3-unsubstituted $\mathrm{N}$-activated aziridine 2carboxylates with para-methoxybenzylamine. The choice of both the $\mathrm{N}$-activating group and ester alkyl group had a significant influence on the ratio of attack at the $\alpha$ or $\beta$ positions of the aziridine. However, the regiochemical outcome is not predictable.
\end{abstract}

\title{
Keywords:
}

1,2-Diaminopropanoic acids (DAPs); Aziridine 2-carboxylates; Ring-opening; Regioselectivity.

Interest in $\alpha, \beta$-diaminopropanoic acids [1,2-diaminopropanoic acids (DAPs)] has expanded over the years, as evidenced by the increase in publications in the area. A recent review, ${ }^{1}$ and its update, ${ }^{2}$ have highlighted methodologies for their synthesis, as well as their possible applications and biological activities. Natural biologically active molecules, which contain the $\alpha, \beta$-diaminopropanoic acid motif, are known and they are stereochemically pure as single enantiomers or diastereoisomers. Therefore methods from the stereoselective synthesis of $\alpha, \beta$-diaminopropanoic acids are very important. In this context, the use of $\alpha$-amino acid derivatives from the chiral pool, where one or more stereocentres are already present, as precursors for $\alpha, \beta$ diaminopropanoic acids, is a key method that has been employed. One of the main routes employed for the synthesis of DAPs is the ring-opening of $\mathrm{N}$-activated aziridine 2-carboxylate esters with primary amines. Although there is a large body of 
literature on the ring-opening of aziridines in general, ${ }^{3}$ as well as 2-acyl aziridines ${ }^{4}$ and $\mathrm{N}$-activated aziridines, ${ }^{5}$ the number of reports on the ring-opening of $\mathrm{N}$-activated aziridine 2-carboxylate esters is fewer. In all such reactions the nucleophile can attack at either the $\alpha$ - or $\beta$-position of the aziridine ring to give regioisomeric products (Figure 1).

In a recent review, ${ }^{3 a}$ De Kimpe and Ha stated that "the regioselectivity in the ringopening reactions of 2-substituted activated aziridines has been shown to be quite straightforward, mostly involving the nucleophilic attack at the less hindered carbon atom, with some exceptional cases comprising the nucleophilic attack at the benzylic position". An examination of the regioselectivity of these reactions shows that the outcome is not always that predictable, ${ }^{6}$ particularly when the nucleophile is a primary amine, and the 2-substituent is also electron-withdrawing (e.g. an ester group). For example, Rich found that reaction of $\mathrm{N}$-tosyl aziridine 2-carboxylic acid with methylamine gave a 1:1 ratio of products resulting from $\alpha$ - and $\beta$-attack. ${ }^{7}$ However, when the steric hindrance at the 2-position was increased, by using the 2tert-butyl ester derivative, the $\alpha: \beta$ ratio was 1:6.3. The van Boom group found a 3.5:1 ratio, in favour of attack at the less hindered $\beta$-position, for the reaction of benzylamine with $N$-ortho-nitrobenzenesulfonyl (o-Ns) azridine 2-t-butyl ester, which increased to a $15-17: 1$ ratio when the primary amine was an $\alpha$-amino acid ester. ${ }^{8}$ When the steric hindrance was increased significantly, by linking the ester group at the aziridine 2-position to a solid support, Olsen found that this led to exclusive attack at the less hindered $\beta$-position, with no evidence for any $\alpha$-attack. ${ }^{9}$ The Franzyk group reported a 9:1 ratio, in favour of $\beta$-attack, when the ester group of an $\alpha$-amino ester was linked to a solid support, and it was reacted with $\mathrm{N}-p \mathrm{Ns}$ aziridine methyl 2carboxylate. $^{5 \mathrm{~h}}$

As part of an ongoing programme of research towards the synthesis of peptides incorporating unusual amino acid residues, we are interested in the synthesis of $\beta$ monoalkyl substituted 1,2-diaminopropanoic acids (DAPs). In particular, the use of orthogonally protected DAPs would allow their incorporation into peptide structures and then their subsequent derivatisation. We previously reported the synthesis, and subsequent use, of such orthogonally protected DAPs for the preparation of 
orthogonally protected azalanthionines (lanazanines), which are nitrogen-linked analogues of the more common amino acid lanthionine (Figure 2). ${ }^{10}$

The required DAPs were prepared by the ring-opening of 3-unsubstituted $\mathrm{N}$-activated aziridine 2-carboxylate esters with benzylamines, or by the Mitsunobu reaction of serine derivatives. ${ }^{11}$ During the aziridine ring-opening reactions it was found that there were issues with the regioselectivity of the reactions, depending on the choice of $\mathrm{N}$-protecting group and ester group at the aziridine 2-position. Since the initial results showed that the regiochemical outcome was not straightforward, an extended study was undertaken to determine whether the regioselectivity was in any way predictable. The required $\mathrm{N}$-activated aziridine 2-carboxylates were prepared as shown in Scheme $1 .^{10,12}$

In each case the protecting groups chosen were those that have been used previously in solid-phase peptide syntheses, particularly in the preparation of lanthionine containing peptides and their analogues. ${ }^{12}$ Thus the N-protecting groups used were Ts, para-nitrobenzenesulfonyl ( $p$-Ns) and para-nitrobenzyloxycarbony ( $p$-Nz), while the methyl and allyl esters were chosen for the aziridine 2-position. Preparation of a DAP with the $\beta$-amino group also being protected was achieved by ring-opening of aziridine 2a with para-methoxybenzylamine $\left(\mathrm{PMB}-\mathrm{NH}_{2}\right)$ following the method of Kim. ${ }^{13}$ This involved heating the reaction to $80{ }^{\circ} \mathrm{C}$ in acetonitrile for 24 hours with two molar equivalents of $\mathrm{PMB}-\mathrm{NH}_{2}$, which gave the two regioisomeric products from nucleophilic attack at either the $\alpha$ - or $\beta$-positions of the aziridine. The PMB group was chosen because it can be easily removed in solid-phase synthesis. The yield of the product (Table 1) from attack at the less hindered $\beta$-position was $32 \%$, while attack at the $\alpha$-position gave a $41 \%$ yield (entry 1 ).

Conducting the reaction at room temperature for 24 hours gave a reversal in the observed selectivity, with the $\beta$-attack giving a yield of $70 \%$ and $\alpha$-attack of $23 \%$ (entry 2). The selectivity observed at higher temperatures was not unexpected, but the $23 \%$ yield of the compound isolated from attack at the hindered $\alpha$-position, at room temperature, was somewhat of a surprise. Since the conditions required to remove the tosyl group are very harsh for solid-phase peptide synthesis the alternative $\mathrm{N}$ - 
activating, peptide-friendly, $p$-Ns and $p$-Nz groups were chosen, for comparison with the $N$-tosyl aziridine 2a. (Note: the $N$-Fmoc protected aziridine was not chosen because it was felt that the secondary amino DAP product might lead to a loss of the Fmoc group). As can be seen, from Table 1, the $p$-Ns protected aziridine methyl ester 3a (entry 3) gave a similar result to aziridine $\mathbf{2 a}(63 \% \beta$ and $21 \% \alpha)$. However, when the $p$-Nz group was used there was no product obtained from attack at the hindered $\alpha$ position, with the DAP product $\mathbf{6 c}$, from attack at the $\beta$-position, being the sole product isolated in a yield of $56 \%$ (entry 4). This result is comparable to the outcome of Harada's study of the reaction of a 2-carboxamido $\mathrm{N}-\mathrm{Cbz}$ aziridine with $\mathrm{m}$ methylbenzylamine in toluene at $80{ }^{\circ} \mathrm{C}$, where the product from attack at the $\beta$ position was the sole product isolated, in a $79 \%$ yield. ${ }^{14}$ It therefore appears that incorporation of a sulfonamide group on the aziridine nitrogen leads to an increase in the amount of nucleophilic attack at the hindered $\alpha$-position. It was thought that perhaps the increased electron-withdrawing properties of the sulfonamide group were responsible for this.

Therefore, in order to extend this study, it was thought that changing the ester methyl group, again to the more peptide-friendly allyl ester group, would be advantageous. However, this small change led to some surprising results (Table 1). To keep the results comparable $\mathrm{PMB}-\mathrm{NH}_{2}$ was again used as the nucleophile. In this case aziridines $\mathbf{2} \mathbf{b}$ and $\mathbf{3 b}$ did not give any reaction products (entries 5 and 6), at either room temperature or at $80{ }^{\circ} \mathrm{C}$ in acetonitrile, while the $p$-Nz aziridine $\mathbf{4 b}$ again gave only $\beta$-attack, giving DAP 6d, in an isolated yield of $66 \%$ (entry 7). The $N$-alloc protected aziridine allyl ester $\mathbf{5 b}$ also did not give any reaction at either room temperature or $80{ }^{\circ} \mathrm{C}$ (entry 8), which was surprising when compared to Harada's study with a Cbz-protected aziridine (vide supra).

It was clear that the observed regioselectivity of ring-opening was not predictable, with small changes in the choice of activating groups leading to quite different outcomes. Since the primary amine employed in these studies was kept constant we next examined the aziridine partner, in order to try to understand the observed regioselectivity. Perhaps an analysis of the ${ }^{1} \mathrm{H}$ NMR chemicals shifts of the $\alpha$ - and $\beta$ - 
protons of the aziridine rings, along with their corresponding carbon chemical shifts in ${ }^{13} \mathrm{C}$ NMR spectra, would help the understanding of the observed results (Table 2).

However, it can be seen that there is very little difference between the analogous ${ }^{1} \mathrm{H}$ and ${ }^{13} \mathrm{C}$ NMR spectral chemical shifts of the aziridines 2-5. It is therefore difficult to make a definitive prediction of the regioselectivity for a particular ring-opening reaction of 3-unsubstituted $\mathrm{N}$-activated aziridine 2-carboxylate esters with a primary amine.

In conclusion, we have shown that the ring-opening of $\mathrm{N}$-activated aziridine 2carboxylate esters with $p$-methoxybenzylamine is far from predictable. We are currently undertaking in-depth computational studies on these reactions, including an examination of possible transition states and their energies, in order to try to understand the experimental results observed. The chemistry is also being extended to the synthesis of the corresponding orthogonally protected $\beta$-methyl DAPs, by ringopening of 3-methyl $\mathrm{N}$-activated aziridine 2-carboxylate esters, en route to the aza analogues of the $\beta$-methyllanthionines found in the ring structures of many important lantibiotics. ${ }^{15}$ The results of all of these studies will be reported in due course.

A typical procedure is exemplified by the synthesis of $\mathbf{6 a}$ and $7 \mathbf{a}$. To a solution of the relevant aziridine $(2 \mathrm{mmol})$ in $\mathrm{CH}_{3} \mathrm{CN}(5 \mathrm{ml})$ was added $p$-methoxybenzylamine $(0.52$ $\mathrm{ml}, 4 \mathrm{mmol}$ ) and the solution was stirred for $24 \mathrm{~h}$ at room temperature. The solvent was removed in vacuo, and then the residue was re-dissolved in EtOAc $(20 \mathrm{ml})$, washed with brine $(2 \times 20 \mathrm{ml})$, dried over anhydrous $\mathrm{MgSO}_{4}$ and concentrated in vacuo. The crude product was purified by flash column chromatography on silica gel in petroleum ether: EtOAc $(2: 1)$.

(L)-Methyl 3-(4-methoxybenzylamino)-2-(4-methylphenylsulfonamido) propanoate $(6 a)$. Colourless oil $(0.54 \mathrm{~g}, 70 \%) ; R_{f}: 0.12$ petroleum ether: EtOAc $(1: 1) ;[\alpha]_{\mathrm{D}}{ }^{20}=$ +13.35 (c 1.0 in $\left.\mathrm{CHCl}_{3}\right)$; ${ }^{1} \mathrm{H}$ NMR $\left(\mathrm{CDCl}_{3}, \delta \mathrm{ppm}\right) 7.72(\mathrm{~d}, 2 \mathrm{H}, J=8.2 \mathrm{~Hz}), 7.28$ (d, $2 \mathrm{H}, J=8.8 \mathrm{~Hz}), 7.16(\mathrm{~d}, 2 \mathrm{H}, J=8.8 \mathrm{~Hz}), 6.85(\mathrm{~d}, 2 \mathrm{H}, J=8.8 \mathrm{~Hz}), 4.03(\mathrm{t}, 1 \mathrm{H}, J=4.8$ $\mathrm{Hz}), 3.79$ (s, 3H), 3.65 (d, 1H, J=12.9 Hz), 3.61 (d, 1H, J=12.9 Hz), 3.52 (s, 3H), $2.88(\mathrm{~d}, 2 \mathrm{H}, J=5.2 \mathrm{~Hz}), 2.40(\mathrm{~s}, 3 \mathrm{H}) ;{ }^{13} \mathrm{C} \mathrm{NMR}\left(\mathrm{CDCl}_{3}, \delta \mathrm{ppm}\right) 171.2,158.7,143.7$, 
$136.6,131.3,129.6,129.3,127.2,113.8,60.4,55.3,52.6,52.3,50.0,21.5$; IR (thin

film, $\mathrm{NaCl}, \mathrm{cm}^{-1}$ ) 3347, 3089, 2981, 1744, 1188, 1150; MS (ES+) for $\mathrm{C}_{19} \mathrm{H}_{25} \mathrm{~N}_{2} \mathrm{O}_{5} \mathrm{~S}$, expected $[\mathrm{M}+\mathrm{H}]$ 393.1479, observed $[\mathrm{M}+\mathrm{H}] 393.1477$.

(D)-Methyl 2-(4-methoxybenzylamino)-3-(4-methoxyphenylsulfonamido) propanoate (7a). Colourless oil $(0.17 \mathrm{~g}, 23 \%) ; R_{f}: 0.24$ petroleum ether: EtOAc $(1: 1) ;[\alpha]_{\mathrm{D}}{ }^{20}=$ +12.41 ( c 1.0 in $\left.\mathrm{CHCl}_{3}\right) ;{ }^{1} \mathrm{H} \mathrm{NMR}\left(\mathrm{CDCl}_{3}, \delta \mathrm{ppm}\right) 7.70(\mathrm{~d}, 2 \mathrm{H}, J=8.6 \mathrm{~Hz}), 7.28$ (d, $2 \mathrm{H}, J=8.0 \mathrm{~Hz}), 7.15(\mathrm{~d}, 2 \mathrm{H}, J=8.6 \mathrm{~Hz}), 6.85(\mathrm{~d}, 2 \mathrm{H}, J=8.6 \mathrm{~Hz}), 5.15$ (br s, 1H) 3.80 $(\mathrm{s}, 3 \mathrm{H}), 3.68(\mathrm{~s}, 3 \mathrm{H}), 3.65(\mathrm{~m}, 2 \mathrm{H}), 3.51(\mathrm{~d}, 1 \mathrm{H}, J=12.9 \mathrm{~Hz}), 3.30(\mathrm{~m}, 1 \mathrm{H}), 3.26(\mathrm{dd}$, $1 \mathrm{H}, J=8.6 \mathrm{~Hz}$ and $J=8.6 \mathrm{~Hz}), 2.95(\mathrm{dd}, 1 \mathrm{H}, J=7.5 \mathrm{~Hz}$ and $J=7.4 \mathrm{~Hz}), 2.41(\mathrm{~s}$, $3 \mathrm{H}), 1.88$ (br s, $1 \mathrm{H}) ;{ }^{13} \mathrm{C} \mathrm{NMR}\left(\mathrm{CDCl}_{3}, \delta \mathrm{ppm}\right) 172.9,158.9,143.5,136.6,131.0$, 129.7, 129.4, 127.0, 113.9, 59.0, 55.3, 52.3, 51.2, 44.2, 21.5; IR (thin film, $\mathrm{NaCl}, \mathrm{cm}^{-1}$ ) 3359, 3082, 2991, 1743, 1224, 1124.

\section{Acknowledgements}

We are grateful to Strand I of the Irish Government's National Development Plan Technological Sector Research Program for funding (Grant PP07/TA07) and the Higher Education Authority's Programme for Research in Third-Level Institutions IV for funding for $\mathrm{K} \mathrm{O} \mathrm{O}^{\mathrm{B}}$.

\section{References and Notes}

1. Viso, A.; Fernández de la Pradilla, R.; García, A.; Flores, A. Chem. Rev. 2005, 105, 3167-3196.

2. Viso, A.; Fernández de la Pradilla, R.; Tortosa, M.; García, A.; Flores, A. Chem. Rev. 2011, 111, PR1-PR42.

3. (a) Stanković, S.; D'hooghe, M.; Catak, S.; Eum, H.; Waroquier, M.; Van Speybroeck, V.; De Kimpe, N.; Ha, H.-J. Chem. Soc. Rev. 2012, 41, 643665. (b) Lu, P. Tetrahedron, 2010, 66, 2549-2560. (c) Schneider, C. Angew. Chem. Int. Ed. 2009, 48, 2082-2084. (d) Pineschi, M. Eur. J. Org. Chem. 2006, 4979-4988. (e) Wu, J.; Sun, X.; Sun, W. Org. Biomol. Chem. 2006, 4, 4231-4235. (f) Hu, X. E. Tetrahedron, 2004, 60, 2701-2743. (g) Cardillo, G.; Gentilucci, L.; Tolomelli, A. Aldrichim. Acta 2003, 36, 3950. 
4. (a) Lee, K. M.; Kim, J. C.; Kang, P.; Lee, W. K.; Eum, H.; Ha, H.-J. Tetrahedron, 2012, 68, 883-893. (c) Yook, C.-M.; Eum, H.; Ha, H.-J.; Kang, K. Y.; Lee, W. K. Bull. Korean Chem. Soc. 2011, 32, 2879-2880. (c) Park, J.-H.; Ha, H.-J.; Lee, W. K.; Généreux-Vincent, T.; Kazlauskas, R. J. ChemBioChem 2009, 10, 2213-2222. (d) Gnecco, D.; Orea, L.; Galando, F. A.; Enríquez, R. G., Toscano, R. A.; Reynolds, W. F. Molecules, 2000, 5, 998-1003.

5. A non-exhaustive list of recent examples includes: (a) Bera, M.; Pratihar, S.; Roy, S. J. Org. Chem. 2011, 76, 1475-1478. (b) Samanta, K.; Panda, G. Chem. Asian J. 2011, 6, 189-197. (c) Ottesen, L. K.; Jaroszewski, J. W.; Franzyk, H. J. Org. Chem. 2010, 75, 4983-4991. (d) Kelley B. T.; Joullie, M. Org. Lett. 2012, 12, 4244-4247. (e) Ghoral, M. K.; Kumar, A.; Tiwari, D. P. J. Org. Chem. 2010, 75, 137-151. (f) Ottesen, L. K.; Olsen, C. A.; Witt, M.; Jaroszewski, J. W.; Franzyk, H. Chem. Eur. J. 2009, 15, 29662978. (g) Moss, T. A.; Fenwick, D. R.; Dixon, D. J. J. Am. Chem. Soc. 2008, 130, 10076-10077. (h) Crestey, F.; Witt, M.; Frydenvang, K.; Staerk, D.; Jaroszewski, J. W.; Franzyk, H. J. Org. Chem. 2008, 73, 35663569. (i) Paixao, M. W.; Nielsen, M.; Jacobsen, C. B.; Jorgensen, K. A. Org. Biomol. Chem. 2008, 6, 3467-3470. (j) Bisai, A.; Bhanu Prasad, B. A.; Singh, V. K. Arkivoc 2007, v, 20-37.

6. For example, see: Tinotta, I.; Fifer, N. L.; Eakins, J.; Hutton, C. A. Tetrahedron Lett. 2013, 54, 618-620.

7. Solomon, M. E.; Lynch, C. L.; Rich, D. H. Tetrahedron Lett. 1995, 36, 4955-4958.

8. Turner, J. J.; Sikkema, F. D.; Filippov, D. V.; van der Marel, G. A.; van Boom, J. H. Synlett 2001, 1727-1730.

9. Olsen, C. A.; Christensen, C.; Nielsen, B.; Mohamed, F. M.; Witt, M.; Clausen, R. P.; Kristensen, J. L.; Franzyk, H.; Jaroszewski, J. W. Org. Lett. 2006, 8, 3371-3374.

10. O’Brien, K.; ó Proinsias, K.; Kelleher, F. Tetrahedron Lett. 2013, 54, 2395-2397.

11. Kelleher, F.; ó Proinsias, K. Tetrahedron Lett. 2007, 48, 4879-4882.

12. (a) Ross, A. C.; McKinnie, S. M. K.; Vederas, J. C. J. Am. Chem. Soc. 2012, 134, 2008-2011. (c) Liu, H.; Pattabiraman, V. R.; Vederas, J. C. 
Org. Lett. 2009, 11, 5574-5577. (c) Liu, H.; Pattabiraman, V.; Vederas, J. Org. Lett., 2007, 9, 4211-4214.

13. Kim, B. M.; So, S. M. Tetrahedron Lett. 1999, 40, 7687-7690.

14. Harada, H.; Morie, T.; Suzuki, T.; Yoshida, T.; Kato, S. Tetrahedron, 1998, 54, 10671-10676.

15. A non-exhaustive recent list includes: (a) Arnison, P. G.; Bibb, M. J.; Bierbaum, G.; Bowers, A. A.; Bugni, T. S; Bulaj, G.; Camarero, J. A.; Campopiano, D. J; Challis, G. L; Clardy, J.; Cotter, P. D.; Craik, D. J.; Dawson, M.; Dittmann, E.; Donadio, S.; Dorrestein, P. C.; Entian, K-D.; Fischbach, M. A.; Garavelli, J. S.; Göransson, U.; Gruber, C. W.; Haft, D. H.; Hemscheidt, T. K.; Hertweck, C.; Hill, C.; Horswill, A. R.; Jaspars, M.; Kelly, W. L.; Klinman, J. P.; Kuipers, O. P.; Link, A. J.; Liu, W.; Marahiel, M. A.; Mitchell, D. A.; Moll, G. N.; Moore, B. S.; Müller, R.; Nair, S. K.; Nes, I. F.; Norris, G. E.; Olivera, B. M.; Onaka, H.; Patchett, M. L.; Piel, J.; Reaney, M. J. T.; Rebuffat, S.; Ross, R. P.; Sahl, H.-G.; Schmidt, E. W.; Selsted, M. E.; Severinov, K.; Shen, B.; Sivonen, K.; Smith, L.; Stein, T.; Süssmuth, R. D.; Tagg, J. R.; Tang, G-L.; Truman, A. W.; Vederas, J. C.; Walsh, C. T.; Walton, J. D.; Wenzel, S. C.; Willey, J. M.; Van der Donk, W. Nat. Prod. Rep, 2013, 30, 108-160. (b) Knerr, P. J.; Van der Donk, W. A. Annu. Rev. Biochem. 2012, 81, 479-505. (c) Montalbán-López, M.; Zhou, L.; Buivydas, A.; van Heel, A. J.; Kuipers, O. P. Expert Opin. Drug Discov. 2012, 7, 695-709. (d) Al-Mahrous, M. M.; Upton, M. Expert Opin. Drug Discov. 2011 6, 155-170. (e) Lee, H.; Kim, H.-Y. J. Microbiol. Biotechnol. 2011, 21, 229-235. (f) Kuipers, A.; Rink, R.; Moll, G. N. Prokaryotic Antimicrobial Peptides, Springer, 2011, 147-169. (g) Asaduzzaman, S. M.; Sonomoto, K. J. Biosci. Bioeng. 2009, 107, 475-487. (h) Piper, C.; Cotter, P. D.; Ross, R. P.; Hill, C. Curr. Drug. Discov. Tech. 2009, 6, 1-18. 

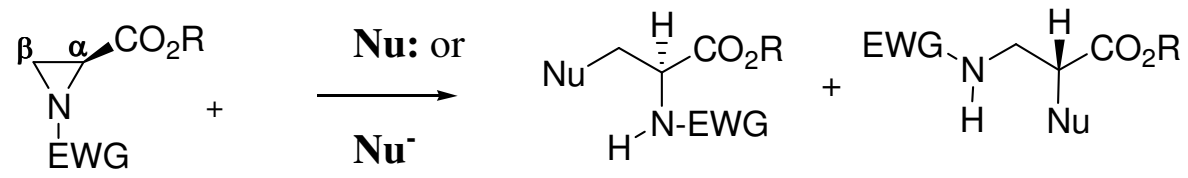

$\beta$-attack $\quad \alpha$-attack

Figure 1: Regiochemistry of nucleophilic ring-opening of $\mathrm{N}$-activated aziridine 2carboxylates

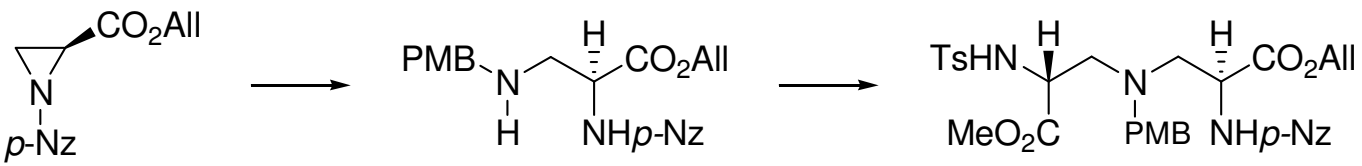

Figure 2: Synthesis of orthogonally protected azalanthionines (lanazanines) ${ }^{10}$
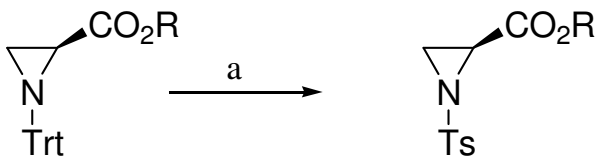

$$
\mathbf{2 a}, \mathrm{R}=\mathrm{Me}
$$

2b, R = Allyl

1a, $\mathrm{R}=\mathrm{Me}$

1b, R = Allyl

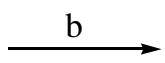

$\sum_{p-\mathrm{Ns}}^{\mathrm{CO}_{2} \mathrm{R}}$

3a, $\mathrm{R}=\mathrm{Me}$

3b, $\mathrm{R}=$ Allyl
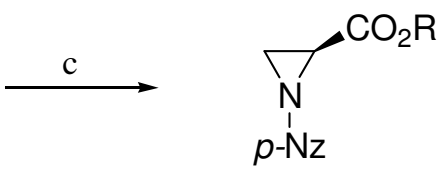

4a, $\mathrm{R}=\mathrm{Me}$

4b, R = Allyl

$\mathbf{1 b}$
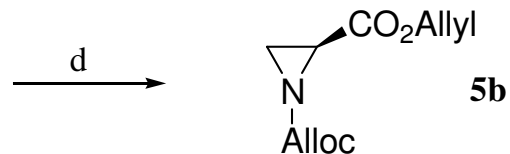

Reagents and conditions; (a) i) $50 \%$ TFA in $\mathrm{CH}_{2} \mathrm{Cl}_{2} / \mathrm{MeOH}(1: 1)$, rt, 30 min, ii) $\mathrm{NaHCO}_{3}, \mathrm{H}_{2} \mathrm{O}$, rt, iii) $p$-TsCl, EtOAc, rt, 24 h, (2a 85\%, 2b 83\%);

(b) i) $50 \%$ TFA in $\mathrm{CH}_{2} \mathrm{Cl}_{2} / \mathrm{MeOH}(1: 1)$, rt, $30 \mathrm{~min}$, ii) $\mathrm{NaHCO}_{3}, \mathrm{H}_{2} \mathrm{O}$, rt,

iii) $p$-nitrobenzenesulfonyl chloride, EtOAc, rt, 24 h (3a 85\%, 3b 80\%);

(c) i) $50 \%$ TFA in $\mathrm{CH}_{2} \mathrm{Cl}_{2} / \mathrm{MeOH}(1: 1)$, rt, $30 \mathrm{~min}$, ii) $\mathrm{NaHCO}_{3}, \mathrm{H}_{2} \mathrm{O}$, rt,

iii) p-nitrobenzyl chloroformate, EtOAc, rt, 24 h (4a 82\%, 4b 82\%); (d)

i) $50 \%$ TFA in $\mathrm{CH}_{2} \mathrm{Cl}_{2} / \mathrm{MeOH}(1: 1)$, rt, $30 \mathrm{~min}$, ii) $\mathrm{NaHCO}_{3}, \mathrm{H}_{2} \mathrm{O}$, rt,

iii) allyl chloroformate, EtOAc, rt, 24 h, 34\%.

Scheme 1: Synthesis of N-activated aziridine 2-carboxylate esters ${ }^{10,12}$ 
<smiles>CC(C)(C)N1[P]C1C(=O)O</smiles><smiles>COc1ccc(CN)cc1</smiles>

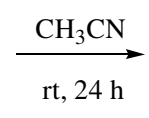<smiles>CC(C)(C)NNC(CNC(=O)O)C(=O)O</smiles>

$\beta$-attack

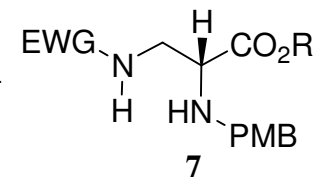

$\alpha$-attack

\begin{tabular}{|c|l|c|c|}
\hline Entry & \multicolumn{1}{|c|}{ Aziridine } & $\% \beta$-attack $^{\mathrm{a}}$ & $\% \alpha$-attack $^{\mathrm{a}}$ \\
\hline 1 & $\mathbf{2 a}(\mathrm{R}=\mathrm{Me}, \mathrm{EWG}=\mathrm{Ts})$ & $32(\mathbf{6 a})^{\mathrm{b}}$ & $41(\mathbf{7 a})^{\mathrm{b}}$ \\
2 & $\mathbf{2 a}(\mathrm{R}=\mathrm{Me}, \mathrm{EWG}=\mathrm{Ts})$ & $70(\mathbf{6 a})$ & $23(\mathbf{7 a})$ \\
\hline 3 & $\mathbf{3 a}(\mathrm{R}=\mathrm{Me}, \mathrm{EWG}=p-\mathrm{Ns})$ & $63(\mathbf{6 b})$ & - \\
\hline 4 & $\mathbf{4 a}(\mathrm{R}=\mathrm{Me}, \mathrm{EWG}=p-\mathrm{Nz})$ & $56(\mathbf{6 c})$ & - \\
\hline 5 & $\mathbf{2 b}(\mathrm{R}=$ Allyl, EWG $=\mathrm{Ts})$ & - & - \\
\hline 6 & $\mathbf{3 b}(\mathrm{R}=$ Allyl, EWG $=p$-Ns $)$ & - & - \\
\hline 7 & $\mathbf{4 b}(\mathrm{R}=$ Allyl, EWG $=p-\mathrm{Nz})$ & $66(\mathbf{6 d})$ & - \\
\hline 8 & $\mathbf{5 b}(\mathrm{R}=$ Allyl, EWG $=$ Alloc $)$ & - & - \\
\hline
\end{tabular}

${ }^{\mathrm{a}}$ Product number is in parantheses; ${ }^{\mathrm{b}}$ Reaction conducted at $80^{\circ} \mathrm{C}$.

Table 1: Regioselectivity of the ring-opening of aziridines with pmethoxybenzylamine.

\begin{tabular}{|c|c|c|c|c|}
\hline Aziridine & $\alpha-\mathrm{H}$ & $\beta-\mathrm{H}$ & $\alpha-\mathrm{C}$ & $\beta-\mathrm{C}$ \\
\hline $\mathbf{2 a}$ & 3.33 & 2.76 and 2.59 & 35.6 & 31.9 \\
\hline $\mathbf{3 a}$ & 3.38 & 2.83 and 2.60 & 36.1 & 32.5 \\
\hline $\mathbf{4 a}$ & 3.09 & 2.57 and 2.45 & 35.0 & 31.4 \\
\hline $\mathbf{2 b}$ & 3.36 & 2.76 and 2.58 & 35.8 & 32.0 \\
\hline $\mathbf{3 b}$ & 3.47 & 2.91 and 2.68 & 36.3 & 32.5 \\
\hline $\mathbf{4 b}$ & 3.22 & 2.65 and 2.57 & 34.9 & 31.4 \\
\hline $\mathbf{5 b}$ & 3.13 & 2.61 and 2.50 & 31.3 & 29.7 \\
\hline
\end{tabular}

Table 2: ${ }^{1} \mathrm{H}(300 \mathrm{MHz})$ and ${ }^{13} \mathrm{C}(75 \mathrm{MHz}) \mathrm{NMR}$ chemical shifts (in ppm) of the $\alpha$ and $\beta$-protons and carbons of aziridines $\mathbf{2 - 5}$, run in $\mathrm{CDCl}_{3}$ 